\title{
Russo-Japanese War Complex: A New Interpretation of Russia's Foreign Policy toward Korea
}

\author{
Youngjun Kim
}

\begin{abstract}
Because human beings are emotional, social and psychological creatures, human beings have prejudice, racism and historical images. Foreign policy is activities of human beings based on human cognition. Therefore, historical legacy and emotional feeling are strongly relevant to a direction of foreign policy. Therefore, it is difficult to understand Russia's foreign policy without understanding of Russian people's history, identity, emotion and humiliation. Because of this, constructivist approach is a very useful tool to analyze a diversity and complexity of foreign policy. In this paper, I argue that materialist explanations of Russia's foreign policy toward Korea are insufficient and constructivism presents a better account of Russia/Korea relations viewed through the prism of intersubjective understanding of Russian role in AsiaPacific, particularly, what I refer to as "Russo-Japanese War complex." The term 'Russo-Japanese war complex' will be defined in this paper as a psychological shock or a collective memory of humiliation to Russian people due to an invasion of Asian people. Russians' fear, insecurity and humiliation from their history in the Northeast Asia function as a point of reference to shape their foreign policy today. Russians' history and identity left its imprint on the Russian perception of "Self" in that region.
\end{abstract}

Key Words: Russian foreign policy, Russian security strategy, constructivism, Russia-Korea relations, Northeast Asian security

ince the end of the Cold War, the relationship between Russia and South Korea has improved. The contrary is true about the relationship between Russia and North Korea. This contrast is not difficult to explain: the prospects of benefitting from economic cooperation with South Korea seems more important to Russia, whose companies have already acquired stock and dividends from investments in Samsung, LG, Hyundai and Kia. Nevertheless, Russia still seems to be an awkward partner of South Korea, largely because of its ties to North

*Youngjun Kim (bumanbake@hotmail.com) is going to work as a professor of International Politics at the Korean National Defense University from 2016. He graduated from the Korea Military Academy, and did postgraduate study at King's College London. He completed PhD at the University of Kansas. His research is about Russian foreign and security policy. His book, Origins of the North Korean Garrison State, will be published worldwide in English at Routledge Press in 2016. He is a Senior International Research Fellow of the US Army Foreign Military Studies Office (FMSO) and his monthly columns have appeared on the FMSO's Operational Environment Watch.

The Korean J ournal of International Studies Vol.13-3 (December 2015), 555-575.

http://dx.doi.org/10.14731/kjis.2015.12.13.3.555

(c) 2015 The Korean Association of International Studies 
Korea and in light of the relations between the two Koreas. For instance, the Cheonan sinking incident of March $26^{\text {th }}$, 2010 clearly showed still ambiguous nature of Russian/South Korean ties, because Russia not only did not clearly support the position of the South Korea government, but also did not side with North Korea(Republic of Korea Ministry of National Defense 2010; Wikipedia 2015). ${ }^{1}$ For the third nuclear weapons test of North Korea in 2013, Russia joined the United Nation's sanctions on North Korea while they announced that they wanted only a peaceful resolution on the North Korean issue with China. Putin visited in Seoul but not in Pyongyang. However, Russo-North Korea relation has improved since the Ukraine crisis. Because of a reaction from Western countries regarding Russia's action during the Ukraine crisis, Russia needs an old friend, North Korea, to escape from its isolated position of the international community. North Korea also needs Russia as an alternative partner to diminish Chinese influence (Kim 2014c, 36; 2014a, 43). Youngjun Kim points out that "if Russia is to take the place of China as the chief protector and supplier for North Korea, the Kremlin would gain not only greater diplomatic status in the region, but also useful political leverage against the US (Kim 2015b, 34; 2015c, 33-34; 2012, 46-47)." Kim explains that Choi Ryong-hae's recent visit to Moscow in November of 2014 was designed to improve Russo-North Korea relations, including increased bilateral trade and investment (Kim 2015a, 38). Militarily, Russia and North Korea also had a mutual interest to counter the US's global prompt Global Strike plan (Kim 2014b, 32). Overall, Russia has maintained two-track foreign policy towards Korean peninsula.

Regarding issues of the Korean peninsula, the positions of the US, China and Japan have always been clear over the last decades. However, the position of Russia still seems ambiguous: it neither publicly supports the South Korean side, nor does it wants to back to her old friend, North Korea. Why does Russia maintain two-track foreign policy towards the Korean peninsula? All explanations of states' foreign policies can be classified into two analytical groups: rational (materialist) explanations, including realist and liberalist' accounts of states' behavior, and ideational explanations informed by constructivism. Whereas realism and

\footnotetext{
${ }^{1}$ Cheonan sinking incident occurred on 26 March, 2010. A South Korean Navy ship carrying 104 navy soldiers sank off near Baengyeong Island in the Yellow Sea and 46 seamen died. International official investigation including South Korea, United States, United Kingdom, Sweden, Canada and Australia concludes that the warship had been sunk by a North Korean torpedo fired by a midget submarine. North Korea government denied its responsibility for sinking. China disputed the claims and finding of the report, and Russia also did not concur with the argument of international official investigation. The United Nations Security council made a Presidential Statement condemning the attack but without identifying the attacker because a lack of support from China and Russia.
} 
liberalism tend to focus on material factors such as power or trade, constructivist approaches emphasize the impact of ideas as well as identities that inform interests of state (Walt 1998, 40).

Many International Relations scholars and political scientists have explained Russian foreign policy in terms of realism and liberalism theoretical frameworks, such as power balance and economic interests. Materialist explanations are useful to explain Russian foreign policy in general. Nonetheless, realism and liberalism explanations are often limited in explaining Russian foreign policy because human beings shape foreign policy with their own understanding of world and their identity. Therefore, understanding people is a very significant in explain a foreign policy. In particular, Russian history and Russian people's historical identity are still unfamiliar topics in Russian foreign policy studies. In this paper, I will explain Russian history and Russian people's historical identities, emotions, feelings and memories regarding the Northeast Asian region. And, within Constructivism theoretical framework, I will demonstrate how Russian people's perspectives and identities throughout their history shape today's Russian foreign policy.

My main argument is that materialist explanations of Russia's position toward the Korean peninsula are useful in general but insufficient. Constructivism presents a better account of Russia/ Korea relations viewed through the prism of intersubjective understandings of Russian role in Asia-Pacific, particularly, what I refer to as "Russo-Japanese War complex." Russians' identity and history left its imprint on the Russian perception of "Self" in that region. In the first section, I will explain an overview of recent Russian foreign policy towards the Korean peninsula. Next, I will lay out the premises of the three theoretical frameworks that I intend to apply for explaining Russian foreign policy toward South Korea. In the third section, although realism and liberalism accounts are useful framework to interpret Russian foreign policy in general, I will demonstrate some cases where realism for explaining Russia's relation with South Korea is insufficient followed by the application and discussion of liberalism. In the section that follows, I will advance two constructivist explanations: Russo-Japanese War complex, and a great power image as a founder of North Korea. In the conclusion, I will summarize the limitations of materialist explanations and usefulness of constructivism explanation to understand recent Russian foreign policy to Korean peninsula. I will conclude that understanding Russians' history, identity, emotion and humiliation is very significant in order to understand a complexity of their foreign policy. 


\section{OVERVIEW OF RUSSIA'S FOREIGN POLICY TOWARD KOREAN PENINSULA: EMPIRICAL QUESTIONS - HOW CAN WE EXPLAIN RECENT RUSSIAN FOREIGN POLICY TOWARDS KOREA?}

In the Northeast Asia, Russia has a long memory, including positive and negative history. In the early $20^{\text {th }}$ Century, many Russian intellectuals and political leaders begun to have interests in Asia and became Eurasianists. Russian historian David Schimmelpennick explains that China's spectacular defeat in a brief war with Japan in 1894-1895 led to St. Petersburg's interest in Asia. Just like the Atlanticists in the US, many Russian politicians and intellectuals had closer ties with Asian countries on the ground politically, economically and culturally (Schimmelpenninck van der Oye 2001, 210-211). These interests became humiliation after the Russo-Japanese War of 1905. Russia gave up its imperial interest in Korea and lost the southern half of Sakhalin Island. In the Far Eastern area, Russia lost its hegemony and Russians felt humiliation because this war was the first defeat of Western countries by Asian country of modern era.

After the Soviet offensive in Manchuria in 1945, the Red Army occupied the north part of the $38^{\text {th }}$ parallel in the Korean peninsula. This operation was very successful and built a great power status of Russia in the Northeast Asia. Stalin agreed with a requirement of the US and the UK about the offensive against the Japanese Empire in order to avoid massive casualties from the Operation Downfall, which was a plan to attack the Japanese mainland. Stalin requested to the US the occupation of Manchuria, Sakhalin Island, Kuril Island and Korea (Whiting 1960, 44; Chen 1994, 108-109; Kraus 2012, 6-7). After finishing the successful Operation August Storm in 1945, Stalin occupied the half of Korea, and provided economic and technical assistance to the North Korean communist government. During the Cold War, North Korea was the symbol of the Soviet Communist Empire in Northeast Asia. The Soviet Union had enjoyed its influence and power in the issues of Northeast Asia via the North Korean regime that was used as a counterbalance to the US policy of containment.

After the collapse of the Soviet Union, the former liberal president Boris Yeltsin signed the partnership with the South Korean government, and broke the traditional partnership with the North Korean government. Yeltsin's first Far Eastern trip as the head of state, in November 1992, was made not to Beijing or Tokyo but to Seoul, where he signed a treaty on the basic principles of Russian-South Korean relations and issued a public apology for the 1983 downing of Korean Airlines flight 007 (Donaldson and Nogee 2005, 288-308). The fear and psychological shock of North Korea from the severance of traditional ties with the Soviet Union motivated the North Korean regime to acquire nuclear weapons. In the 
past, the Soviet Union refused North Korea's 1963 request for help in developing military nuclear program and North Korea quickly tried to use its own nuclear and missile program as bargaining chips with its neighbor countries (Harrison 2002, 201-204).

The Russian/South Korean relationship has been strengthened since the collapse of the Soviet Union. South Korean President Roh Tae-woo announced the Northern policy to normalize relations with the Soviet Union and committed to provide 3 billion dollars to the Gorbachev administration. Many South Korean companies began to trade with the Soviet Union in 1990, and Seoul and Moscow started to have a discussion about the Nakhodka Free Economic Area in the Russian Far East, gas-field development in Irkutsk, and the Trans-Siberian railroad. The Putin government joined several U.N. sanctions on the North Korean regime in terms of the partnership with the US and South Korea. When interKorea relations were good under the Kim Dae-Jung and the Roh Mu-Hyun administration of South Korea, Russian government argued the joint project between Russia and the two Koreas for a construction of the Trans-Siberian railway. Putin still argues that a discussion for the project of Trans-Siberian railway between Russia and the two Koreas must restart as soon as possible in the Seoul G-20 summit in 2010. The collapse of the Soviet Union was a turning point of Russia's foreign policy towards two Koreas. For the last two decades, the relationship between Russia and South Korea has been improving in a contrast to the relations of Russia with North Korea.

However, the Putin and the Medvedev government have not been engaged in building alliances in Northeast Asia suggesting that neither South Korea nor North Korea have been perceived as a threat. Although the Russian government established the Shanghai Cooperation Organization (SCO) with China against the unipolarity of the US government, this did not mean a strong anti-Western alliance similar to the triangle partnership between the Soviet Union, China and North Korea during the Cold War.

On March $26^{\text {th }}, 2010$, the Cheonan, a South Korean navy ship carrying 104 personnel, sank off in the Yellow Sea, and 46 personnel died. The South Korea-led international official investigation, including members from the US, the UK, Canada and Sweden, concluded that the ship was attacked and sunk by a North Korean torpedo, and the torpedo was fired by a midget submarine. International community, excluding China which maintains a pro-North Korea foreign policy, criticized the activity of the North Korean regime. The United Nations Security Council (UNSC) condemned the attack, but the UNSC did not identify who the attacker was, because of a lack of support in China, and an ambiguous attitude of Russia. Russian navy experts visited South Korea and returned to Russia with a 
sample for further analysis in May 2010. It seemed that the Russian government did not want to announce an official statement throughout 2010, and no official statement on the assessment from the Russian government had been made. For the North Korean third nuclear weapons test in 2013, Russia joined the United Nation's Sanctions on North Korea while they announced that they wanted only peaceful resolution on this issue with China.

Regarding the Cheonan incident, Russia supported neither the argument of the South Korea government nor the argument of the North Korean government. Had Russia's policy toward two Koreas been driven by economic interests in accumulation of wealth, it should have supported its economic partner, South Korea. Had Russia been motivated by the goal of counterbalancing against US interests in Northeast Asia, it should not have joined UN sanctions against the North Korean regime. What explains Russia's two track foreign policy toward the Korean peninsula? The following section will explain three theoretical frameworks that I want to apply and I will demonstrate how neither realism nor liberalism can account for the ambiguous position of Russia toward South and North Koreas.

\section{THEORETICAL FRAMEWORKS: REALISM, LIBERALISM AND CONSTRUCTIVISM}

Realists emphasize the balance of power as a solution to the question of survival in international relations, characterized by anarchy and the absence of a central authority in the world of sovereign independent states. Realists hypothesize that states will form alliances with other states to balance against the growing influence of great powers (Walt 1998, 30-31). Domestically, a state will build its military and economic capabilities to be able to project its power internationally. On the other hand, liberalists emphasize economic interdependence to account for international cooperation and the impact of domestic interest groups have on shaping a states' foreign policy (Rittberger 2004, 4-6).

Russian foreign policy expert Andrei P. Tsygankov points out that "both realism and liberalism view Russia's foreign policy in terms of similar Western cultural lenses and do not read Russia's indigenous history and system of perceptions." Both realists and liberalists see that the international system is a terrain for applying available military, economic, and diplomatic tools. Realism and liberalism developed in the West, these approaches have their own limitations to interpret multicultural and multi-meaningful world (Tsygankov 2010, 14). Stephen M. Walt explains that both realism and liberalism both failed to antici- 
pate the end of the Cold War and had trouble explaining it while constructivism had an explanation, specifically Mikhail Gorbachev's foreign policy based on "common security." (Walt 1998, 41).Constructivists see international system as a cultural or social phenomenon. From this perspective, assisting states in their understanding of interests and socialization in world politics is the role of international system. Identity is the core concept of the constructivist theory. According to Walt, "nations first seek to figure out what their interests in the international society are before they understand how to defend their interests with their means. Nations find their national identity by interacting with other members of the international society and understanding self's emotional, cognitive, and evaluative orientations towards its others (Ibid., 15-17)." In this context, constructivism is a very useful framework to explain many aspects of international phenomenon and foreign policy actions of nations. In the Russia's foreign policy realm, both realist and liberalist approaches are dominant theoretical frameworks to explain Russia's foreign policy actions. In this paper, constructivist approach is a useful theoretical framework to explain a current Russia's foreign policy towards the Korean peninsula and understand its origins.

\section{LIMITATIONS OF REALIST APPROACH TO RUSSIA'S FOREIGN POLICY TOWARDS KOREA}

Russia has maintained a good relationship with South Korea since the end of the Cold War because Gorbachev and Yeltsin expected economic interest from South Korea. The Russian government borrowed about 3 billion dollars from South Korea, and sent their weapons, including tanks and missiles, and technical assistance to South Korea instead of returning money. Traditionally, sharing weapons and technology about weapons means a high-level of trust between two states and the initial stage for the military partnership. For instance, Stalin provided many tanks and weapons to Kim Il Sung before the Korean War, and many North Korean officers were educated in the Soviet military school before and after the Korean War. Mao Zedong borrowed several military bases and North Korean soldiers from North Korea during the Chinese Civil War, and rent Chinese soldiers to support Kim Il Sung during the Korean War (Millet 2005, 194-197). When Hitler and Stalin had a good relationship from 1939 to 1941, Germany and the Soviet Union shared many military technologies (Glantz 1998). Russia does not perceive South Korea as a threat because Russia is sharing military weapons and technologies with South Korea. In reaction to Moscow's tilt toward South Korea, North Korea angrily described Moscow's arms sales to Seoul as a criminal act that 
showed that "Russia itself is all but in the camp of forces hostile to North Korea." Yeltsin declared that the 1961 Soviet-North Korean security treaty "has lost its effectiveness and exists in name only" (Donaldson and Nogee 2005, 288-308). Russia has never blamed the US-South Korea military exercise since the end of the Cold War. The Russian government stated that the role of the US military should be an international police and balancer in Northeast Asia, even after the reunification of the two Koreas (Harrison 2002, 338-346).

During the Cold War period, realism accounts were very useful in explaining the Soviet Union's position in the Northeast Asia. In terms of a balance of power, the Soviet Union needed to support North Korea. However, realism accounts have been not a sufficient framework in explaining recent Russia's foreign policy positions regarding two Koreas, especially during the Putin-Medvedev administration period.

In terms of realist approach, if Russia wants to maintain a balance of power, a tradition of three to three alliances (Russia-China-North Korea vs The US-JapanSouth Korea) would be useful. However, Russia did not attempt to re-establish this three to three tradition of balance of power in Northeast Asia after the end of the Cold War. Russia also became a partner to South Korea and the US and said good bye to its old unpopular friend, North Korea. Russia has not been engaging in building alliances in Northeast Asia. SCO does not equal the strong military partnership, just like the US-South Korea alliance or NATO. If Russia wants to maintain her influence and power in the Northeast Asia, anti-US alliances or negative reactions to the US military activity in this region would be reasonable. However, Russia has not blamed the US-South Korea joint military exercises, while China and North Korea always blamed the US military activity in Northeast Asia. Indeed, Russia agreed with many UN sanctions to North Korea, which the US has always led. It seems Russia neither wants to be a military power in this area, nor it wants to maintain its traditional alliance with North Korea. The realist approach cannot explain the ambiguous attitude of Russian government towards the Cheonan sinking incident. Realist explanations, such as a balance of power and survival, are inadequate for an ambiguous recent Russian foreign policy to two Koreas.

\section{LIMITATIONS OF LIBERALIST APPROACH TO RUSSIA'S FOREIGN POLICY TOWARDS KOREA}

During the Yeltsin period, liberalism accounts were very useful because Russia wanted to get economic interests by normalizing a relation with South Korea. 
Nonetheless, liberalism accounts cannot explain today's Russia's position in an effective way rather than before.

Recent Russia's foreign policy position, including the Cheonan case and an improved relation between Russian and North Korea, liberalists can argue that the Russian government was reluctant to support the South Korean government because of a lack of cooperation between Russia and South Korea. They explain the lack of cooperation through weak economic ties or weak interdependence between the states. However, the two countries have had a strong mutual economic interest and strong interdependent relations for the last two decades. The South Korean government wants Russia as a large market and its resources, such as gas and oil. The Russian government needs an investment from South Korean companies, particularly in its Far East area, and wants to restart a construction project for the Trans-Siberian railway with the South Korean government. It is true that there has been no economic interdependence between Russia and North Korea for the last two decades.

Regarding the Cheonan sinking incident, liberalists can explain the Russian government's lack of support towards the South Korean government because of inadequacy of international institutions in uniting Russia and South Korea. However, for the last two decades, the Russian government has always supported the position of the South Korean government on the United Nations Security Council sanctions on the North Korean regime, except for the Cheonan sinking incident. Furthermore, the Russian government has had many formal and informal meetings with the South Korean government in the international institutions, such as the G-20 summit and APEC.

Liberalists can argue that the Russian government did not fully support the South Korean government regarding the Cheonan sinking incident, because of a lack of pro-South Korean domestic interest groups in Russia or the presence of powerful interests within the country that support Russia's ties with North Korea. First of all, there was no economic, diplomatic and military interdependent relation between Russia and North Korea for the last two decades. This means that there are few pro-North Korean domestic interest groups in Russia. On the other hand, many pro-South Korean domestic interest groups and pro-South Korean Russian companies have existed in Russia for economic reasons. For the last two decades, massive investment from South Korean companies and an export of South Korean products have led to not only pro-South Korean Russian companies for economic interests, but also pro-South Korean tendency in Russia. Because of massive trades and personal interactions between South Korea and Russia for the last two decades, it led to many pro-South Korean companies and individuals in Russia. For instance, Putin has a strong personal tie with a South 
Korean family. Putin's second daughter has had a close relationship with a South Korean man, who worked for the LG in Moscow, and a son of a former Korean military attaché and admiral in the South Korean Embassy on Moscow for the last decade. Putin's daughter often stayed in her South Korean boyfriend's home in South Korea and had a dinner with her boyfriend's parents. Putin invited his daughter's South Korean boyfriend to his house and allowed his daughter to remain in this relationship for the last decades (Osborn 2010; Ahn 2010). We cannot oversimplify this example, and cannot say that it proves either Russia's good relationship with South Korea or an influence of pro-South Korean domestic interest groups in Russia. Nevertheless, at least, it shows Russia's better relationship with South Korea than North Korea. Furthermore, it seems that there are few pro-North Korean domestic interest groups in Russia after the end of the Cold War, while many Russian companies and individuals support a better relationship with South Korea for economic or personal reasons.

To sum up, those liberalist explanations are not enough to explain the Russian government's lack of support to the South Korean government regarding the Cheonan sinking. Economic interdependence between Russia and South Korea has been increased since the collapse of the Soviet Union, and the relation between Russia and South Korea has generally been great because of mutual economic interest. In terms of mutual economic interest and strong economic interdependence between Russia and South Korea, Russia should have supported the position of South Korean government about the Cheonan sinking incident in 2010. It is clear that there are little interdependent relations between Russia and North Korea. Nevertheless, the Russian government's position was very reluctant to support the South Korean government's argument, and did not blame the attack of the North Korean government. Similarly, the Russian government did not agree with the UN's presidential announcement blaming the North Korean government for the attack on the South Korean ship. At the same time, the former President Medvedev requested to restart a construction project for the Trans-Siberian railway to the South Korean government and massive investment of South Korean companies into the Russia's Far East. It does not seem that Russia wants economic interest from North Korea in a bigger picture although a substantial number of North Korean workers worked in the farm and factory of the Far Eastern area. The liberalist approach cannot explain the ambiguous position of Russian government. The liberalist explanations are inadequate for the ambiguous Russian Foreign Policy toward the Koreas recently.In the next section, I will apply a theoretical framework of constructivism to Russia's foreign policy towards Korea with Russians' historical experiences and their identity in the Far Eastern region. 


\section{CONSTRUCTIVIST APPROACHES TO RUSSIA'S FOREIGN POLICY TOWARDS KOREA}

People's historical experiences function as a point of reference to shape their foreign policy. People's historical experiences naturally become their identity, ideas and discourses to make their foreign policy. Therefore, it is difficult to understand Russia's foreign policy without understanding of Russian people's history, identity, emotion and humiliation. In this section, I create the term 'Russo-Japanese War Complex' to explain Russo' identity to shape their foreign policy towards Korea from their historical experiences in the Far Eastern region. I define the term 'Russo-Japanese War Complex' as Russians' fear, insecurity and humiliation from their historical experiences in that region. I argue that this complex has been a powerful force to shape today's Russia's foreign policy in that region.

\section{RUSSO-JAPANESE WAR COMPLEX}

The Russo-Japanese War complex still influences Russian foreign policy in Northeast Asia. The term 'Russo-Japanese War Complex' will be defined in this paper as a psychological shock or a collective memory of humiliation to Russian people due to an invasion of Asian people who have been regarded as an inferior nation to Slavic or European people's militarily, economically and cultural aspect (Harrison 2002, 328-331). This complex does not mean a fear of Japan, but a fear of potential threats from the growth of Asian countries, such as China, Japan and Korea in the Russia's Far Eastern area, including a part of Manchuria, Kuril Island, Sakhalin Island and Vladivostok area. Russia's humiliation became an important memory to Russian people that also informs its social identity, one of the key concepts in constructivism. For example, according to Putin's speech, "I do not want to dramatize the situation, but if we do not make real effort, even the indigenous Russian population will soon speak mostly Japanese, Chinese, and Korean."

From Mongol warrior Genghis Khan to the Japanese Empire, Russia's Asian neighbors have been marked by fear and defensiveness because of large open borders (Donaldson and Nogee 2005, 17-36). The historical memory of fear in the Far Eastern area contributed to a militarization of the Soviet economy and society. For instance, the 1931 Manchurian crisis was the most important external factor for a beginning of mass mobilization and a militarization of Soviet economy and society during a rapid industrialization era from 1927 to 1941 (Stoecker 1998, 59-71; Samuelson 2000, 154-156; Stone 2000, 184-209). Ironically, this 
kind of historical collective memory from the Far Eastern area contributed to a superiority of Soviet military during the Second World War and the Cold War as well as a collapse of the Soviet Union in 1991.

Indeed, Joseph Stalin, Mikhail Tukhachevsky, the Chief of the General Staff, and Kliment Voroshilov, the Defense Minister, finally decided a massive industrialization and a militarization of the Soviet economy and society, because of a fear against Asian people's invasion such as the Japanese Empire to the Far East and the 1931 Manchurian crisis (Stoecker 1998, 189-195; Samuelson 2000, 154155). Stalin drew a special attention to the 1931 Manchurian crisis and seriously concerned the Far Eastern threats.Volosilov visited to the Far East during the summer of 1931, he became a strong supporter for a militarization of the Soviet Union after his visit. Because of this threat from the Far East in 1931, a defense budget of the Soviet Union was rapidly increased (Stoecker 1998, 64-69).

In terms of the historical background in the Far Eastern area, Russian people do not want to lose their images as a great power and an important actor in this area. At the same time, they do not want to be ignored by Asian people such as China, Japan and two Koreas. For instance, the Great Peter wanted to make the Russian Empire a part of Europe and treated Asian people and traditions from Mongolian as an inferior civilization (Stone 2006, 148-154). Russian intellectuals such as Moscow University's history professor Mikhail P. Pogodin (18001875) who had racial imperialism believed that Russians need to civilize Asians (Hauner 1990, 38-41). During the Russian Civil War, Trotsky and Lenin completely annihilated the Asian soldiers of the White Armies in the Far East, and more surprised by the threats of unexpected Japanese intervention in the Far East than the expected Western intervention in the European theater (Mawdsley 2005, 230-241; Lincoln 1989). During the Operation August Storm in 1945, the Soviet soldiers' war crimes were more bloody and harsh to Chinese, Japanese and Korean people than the German people in Europe, because of Stalin's unwillingness to defense Asian civilians and prisoners as well as his racism and orientalism toward Asian people. The image of Asian people to Russian people and Russian people's prejudice toward the Asian people were not very different from that of images and prejudices of the United States or Western Europe. Asian people's image was a less civilized monkey (Dower 1986). Russian people had a similar image and prejudice to Asian people. This led to more harsh and bloody wars against Asian people without mercy. The Soviet soldiers raped many Asian girls and women and killed many senior people and children of Asian population in Manchuria (Armstrong 2003, 44). Because of liberator Soviet soldiers' war crimes and aggressiveness to Asian civilian in Manchuria and the Far East, many Chinese and Korean people in this area returned to Chinese mainland and Korean 
peninsula (Millet 2005, 49-50). The Soviet army feared a revival of Asian power in the Far East, and wanted to annihilate any possibility of potential Asian enemy in the Far East.

The bad memories from the Russian/Japanese War and 1931 Manchurian crisis were unforgettable lessons to the Soviet Army. The Far East was very far from Moscow or Leningrad, and many Asian people lived in this area. The Soviet leaders needed a buffer zone and ice-free seaports for defending and governing the Far East. Stalin wanted to occupy not only Manchuria but also the Japanese mainland and Korean peninsula during the Operation August Storm in 1945 for making a buffer zone and a dominance in the Far East (Hasegawa 2005). Because of the arrival of the US forces in Japan and South Korea, the Soviet Army stopped their movement from North Korea and Kuril Island to South Korea and the Japanese mainland. Because of an open border and a long distance from the capital, the Soviet leaders have always feared potential threats from China and Japan, so they wanted buffer zones (Millett 2005, 48-50).

Racism toward the Asian people was connected more harsh military strategy of the Soviet Union in the Far East. Stalin ordered Chinese and Korean people to move from the Far East to Central Asia such as Kazakhstan and Uzbekistan, not only for an economic reason such as labor but also security reasons. This led to massive casualties and diseases of Asian people because of a lack of material such as food and health care support from the Soviet government. Russian people's racism and Russo-Japanese War complex was a fundamental reason for making North Korea a buffer zone and more harsh military operations in the Far Eastern area (Kokoshin 1998, 95; Svechin 1927, 25-37).

Russian people still suffer from a Russo-Japanese War complex. Russian people had suffered from a humiliation in Northeast Asia because of the unexpected defeat from the Russo-Japanese War in the early $20^{\text {th }}$ Century. It was the first time that a Western Empire lost a war against the Asian country. After that, the Western Empire such as Great Britain, France, Germany and the United States ignored Russian power during the Inter-War Period from 1919 to 1939. Even the Japanese Empire invaded Russian territory from Vladivostok to Central Asia during the Russian Civil War (Mawdsley 2005, 230-241). It was a bad memory for Russian people. Russian people were surprised and humiliated by Asian people, who they generally had ignored. Russians had traditionally ignored Asian people and countries and had admired the Western power and culture. Moreover, most Russian people and leaders have recognized themselves as a part of Europe, not Asia. For instance, Putin explicitly sided with Europe and the US and insisted that Russia was a country of European and Western, rather than Asian, identity. Putin's speech about fear of Asian people was connected with a general memo- 
rization of the historical experiences from the Russo-Japanese War and racism (Tsygankov 2010, 146). Although the Soviet Union enjoyed its great power in this area again during the Cold War, the Soviets generally worried its insecurity in that region during the Cold War because of their experiences about foreign invasions during the Russian Civil War and the Second World War (Mastiny 1996). After the end of the Cold War, Russian influences have declined in that region.

The pride and historical experiences of Russian people in the Far Eastern area is different from those of the European area. The Russian government wants to remain in an important role in the Far Eastern area and Northeast Asia, because the potential threats from inferior Asian people such as Chinese, Korean and Japanese will increase in the near future without Russian government's continued engagement in this area. Most people in the Far Eastern area are now Chinese-Russian and Korean-Russian, and originate from Asian countries. Without Russian government's continued engagement in the issues of the Far Eastern area and Northeast Asia, the economic and military growth of China, Japan and Korea would be real threats to that region. Putin himself warned an audience in the Russian Far East that unless steps were taken to develop the region, people there within a few decades would be speaking mostly Chinese, Japanese, and Korean. Russia hoped to play a role in regional security arrangements that would foster stability and promote expanded trade, but neither Tokyo nor Seoul responded to Moscow's overtures with the degree of enthusiasm for which the Russians had hoped (Donaldson and Nogee 2005, 288-308).

The former President Medvedev's visit to Kuril Island and a recent military build-up in Kuril Island were relevant to these kinds of considerations. Russia does not want to be an automatic pro-US follower in this region, because Russia wanted to be recognized as an important strategic key player. Russia does not want to be excluded from a main table to discuss key issues regarding Northeast Asia and Korean peninsula, and does not want to be recognized as an automatic pro-US follower in this region. Russia wants to be recognized as an important country, and maintain its dominance and influence in the Far East area.

In particular, emerging security challenge to Russia's Far East from a Chinese military became a major issue among Russian military and security experts. In a bigger picture, Russian and China have a diplomatic tie against the US hegemony. Nonetheless, a relation between Russia and China has been complex since Stalin-Mao period. A tension and rivalry between China and Russia has a long historical root. Joseph Stalin concerned the rise of powerful China in the Northeast Asia right after the end of Chinese Civil War. Even Stalin had a negotiation with Chinese Nationalists during the Chinese Civil War and did not support Mao's army (Shen 2011;Shen and Li 2012). Mao felt a humiliation. During 
the Russian Civil War, Mao did not support the Red Army. After the Korean War, the Sino-Soviet conflict was a major tension during the 1960's. After all, Nixon and Kissinger opened a door of China and isolated the Soviet Union diplomatically. Therefore, Russian's fear of China's rise seriously influenced Russian foreign policy towards Northeast Asia, including two Koreas.

Recent Vostok-2010 between late June and early July, 2010, the large exercise in Siberia and the Russian Far East Command conducted, was a good example. The enemy of this large military exercise was an unnamed large massive ground forces. Although the enemy was unnamed, it was easy to speculate that large massive ground forces was neither the US nor Japan, but China. In this context, Russia's nuclear arsenals still remain a key security measure in the Far East area. Recent Russia's defense reform has focused on small-size brigade units and a decrease of military district from six to four. Russia's nuclear weapons became more significant security measure in the Far East area where small number of Russia's conventional forces would remain. Russian military deployed two newly organized brigades along the Russian-Chinese border on the Irkutsk-Chita Axis and its mission is to counter the presence of five PLA combined arms armies across the border (Kipp 2011, 469). The Russian Military Doctrine 2000 emphasized an emerging threat from China although there was no officially mentioning a name of China in the doctrine due to a concern of a reaction of China. Chinese threat was new in military doctrine and Russia concerns about military exercises conducted by the PLA which may have rehearsed a future Chinese military intervention in Russia or Central Asia (McDermott 2013, 20-21). General Makhmut Gareev, the founder and the head of the Academy of Military Science in Russia, points out an emerging threat of modernized and massive PLA. Gareev mentioned the outbreak of local fighting between the Soviet Union and China along the Amur River in 1869 that forced the mobilization of an entire military district (Kipp 2011, 464-465).

In conclusion, the Russo-Japanese War complex, its fear of the growth of Asian countries and its hope for key strategic initiative regarding regional issues, which was strengthened by racism, can be an important factor to explain a recent Russian dual foreign policy to two Koreas in terms of constructivism. This background contributes to the Russian's strategic decision about the Cheonan sinking incident. Thus, North Korea is still important to Russia as a buffer zone, a key image as well as an important agenda which needs Russia's decision in this area. 


\section{A GREAT POWER IMAGE OF RUSSIA AS A FOUNDER OF NORTH KOREA}

North Korea is still an important symbol to Russian people as a legacy of the Soviet power in Northeast Asia. Russian people do not want to lose their images as a great power and an important actor in this area. If North Korea collapses, it would mean a collapse of a legacy and a role of Russian power in the Northeast Asia. After the end of the Cold War, Russia became a partner to South Korea and broke a close relationship with North Korea. Nevertheless, North Korea is still important symbol as a Russian power to international people in Northeast Asia. Without North Korea, Russian people do not have any legacy in Northeast Asia. Without North Korea, an image of important actor of Russia in this area would disappear. Although it seems North Korea is not helpful for Russia economically and militarily, a continuation of North Korean regime provides many opportunities as a role of important actor to Russia in Northeast Asia such as the Six Party talks. Without North Korea, China, the United States, Japan and South Korea do not want an intervention and a participation of Russia as an important actor regarding issues of Northeast Asia. The end of the North Korea regime would mean the end of the last legacy of the Soviet power in Northeast Asia.

Since the end of the Cold War, Russians experienced a profound identity crisis. Russian foreign policy expert Mariya Y Omelicheva explains that it is because "the collapse of the Soviet Union accompanied by the loss of territory and division of the military and industrial property and infrastructure emasculated Russia (Omelicheva 2012, 100).” Russian people want to have a great power status. Firstly, Foreign Minister Andrei Kozyrev conductedpro-Western foreign policy with President Yeltsin's support. However, Kozyrev's foreign policy was failed because not only the West itself did not satisfy Yeltsin's and Kozyrev's expectation and treated Russia more as a dependent client that as a full participant but also statists strongly attacked that Kozyrev's foreign policy only led weak Russia's international status (Tsygankov 2010, 85). Therefore, the new Foreign Minister Yevgeni Primakov started so-called Great Power Balancing foreign policy to balance Russian power against Western countries. Today's Russia's actions in Georgia, Chechen and Ukraine are continuities of Primakov's Great Power Balancing foreign policy. These Russia's actions are strongly relevant to Russian people's aspiration towards a revival of Great Russia. Omelicheva points out that Russia never surrendered its great power. She explains that "Russia's nuclear status is one of the very few issues in politics of the Russian Federation that generate overwhelming consensus because Russian politicians, scholars, military elite, servicepersons, general population, and even the Russian Orthodox Church sup- 
port Russia's nuclear standing (Omelicheva 2011, 9).”

Youngjun Kim and Raymond Finch of the US Army Foreign Military Studies Office (former Soviet Army Studies Office) at Fort Leavenworth published a special essay on Russia and the New North Korean Leader. They analyze that Vladimir Putin's visit to North Korea in July 2000 as a sign that "Putin was intent upon re-establishing Russia's prestige abroad and its sphere of influence in the East." They also point out that "Putin was demonstrating an independent foreign policy by visiting the 'rogue' regime in Pyongyang and this was a turning point of Russia's foreign policy because Russia had largely spurned North Korea in the 1990s, adopting a pro-Western foreign policy (Kim and Finch 2013, 55)." Kim and Finch conclude that the legacy of both the Cold and Korean Wars continues to shape how Putin views North Korea and he hopes to maintain good relations with both Koreas (Ibid., 56).

Russian people do not want to be recognized as a decline of great power by international people and the Northeast Asian countries. Although North Korea is not useful to Russia anymore economically and militarily, this regime is still needed as a symbol and legacy of great power to Russian people in the Northeast Asia. In terms of Constructivism, North Korea still remains a pride and a legacy of great power to Russian people as a social norm.

\section{CONCLUSION}

To sum up, international events cannot be explained by only one perspective, either realism or liberalism or constructivism. Materialist approach has dominated in international relations and academics. However, it is not enough to explain the complexity of international events, and a state is not one-unitary rational actor. Foreign policy is made by different departments and different people. It includes public opinion, collective cognition, psychological effects, personality of leaders and historical complex. Foreign policy is about activities of human beings, not about activities of robots. Human beings are emotional, social and psychological creatures. Human beings have pre-understandings, prejudice, racism and historical images. That is why many international events and foreign policy cannot be explained by only money and power.

Regarding the relationship between Russia and South Korea, constructivist approach is a very useful theoretical framework to explain the complexity of Russian government position. Money and power are not enough to explain the activities of human beings. Historical legacy and emotional feeling are strongly relevant to a direction of foreign policy, and constructivist approach is very use- 
ful tool to analyze a diversity and complexity of foreign policy.

\section{REFERENCES}

Ahn, Sung-gyu. 2010. "Daughter of Putin falls in love with a Korean man." Korean Joongang Daily (October 29). Accessed at http://joongangdaily.joins. com/article/view.asp?aid=2927699(October 14, 2015).

Armstrong, Charles K. 2003. The North Korean Revolution, 1945-1950. Ithaca, NY: Cornell University Press.

Baylis, John and Steve Smith. 2006. The Globalization of World Politics: An introduction to international relations. $3^{\text {rd }}$ Edition. Oxford: The Oxford University Press.

Chen, Jian. 1994. China's road to the Korean War: the making of the SinoAmerican confrontation. New York: Columbia University Press.

Cumming, Bruce. 2010. The Korean War: A History. New York, NY: Modern Library.

Donaldson, Robert H. and Joseph Nogee L. 2005. The Foreign Policy of Russia: Changing Systems, Enduring Interests. $3^{\text {th }}$ Edition. Armonk, NY: M. E. Sharpe.

Dower, John W. 1986. War without Mercy: Race and Power in the Pacific War. New York, NY: Pantheon Books.

Glantz, David M. 1998. Stumbling Colossus: The Red Army on the Eve of World War. Lawrence, KS: The University of Kansas Press.

Glantz, David M. and Jonathan M. House. 1995. When Titans Clashed: How the Red Army Stopped Hitler. Lawrence, KS: The University of Kansas Press.

Harrison, Selig S. 2002. Korean Endgame: a Strategy for Reunification and US disengagement. Princeton, NJ: Princeton University Press.

Hasegawa, Tsuyoshi. 2005. Racing the Enemy: Stalin, Truman, and the Surrender of Japan. London: The Belknap Press of Harvard University.

Hauner, Milan. 1990. What is Asia to Us? : Russia's Asian Heartland Yesterday and Today. Boston, MA: Unwin Hyman.

Kim, Youngjun. 2012. "Putin's Pivot to Asia." Operational Environment Watch 2(5), 46-47. Accessed at http://fmso.leavenworth.army.mil/OEWatch/ 201505/201505.html(October 14, 2015). . 2014a. "Ukrainian Fallout in North Korea." Operational Environment Watch 4(6), 43. Accessed at http://fmso.leavenworth.army.mil/ OEWatch/201406/201406.html(October 14, 2015). . 2014b. "North Korea's Alliance with Russia against Prompt Global 
Strike." Operational Environment Watch 4(11), 32. Accessed at http://fmso.leavenworth.army.mil/OEWatch/201411/201411.html(Octo ber 14, 2015).

. 2014c. "Pyongyang and Putin's Propaganda." Operational Environment Watch 4(12), 36. Accessed at http://fmso.leavenworth.army.mil/ OEWatch/201412/201412.html(October 14, 2015).

. 2015a. "Expanding Korean-Russian Relations." Operational Environment Watch 5(1), 38. Accessed at http://fmso.leavenworth.army. mil/OEWatch/201501/201501.html(October 14, 2015).

. 2015b. "North Korean Leader to Moscow?" Operational Environment Watch 5(2), 34. Accessed at http://fmso.leavenworth.army.mil/ OEWatch/201502/201502.html(October 14, 2015).

. 2015c. "Rosy Russian View of North Korea." Operational Environment Watch 5(3), 33-34. Accessed at http://fmso.leavenworth.army.mil/ OEWatch/201503/Korea_o1.html(October 14, 2015).

. 2015d. "North Korean Leader at Russian Victory Parade" Operational Environment Watch 5(5), 67-68. Accessed at http://fmso.leavenworth. army.mil/OEWatch/201505/201505.html(October 14, 2015).

Kim, Youngjun and Finchness, Raymond. 2013. "Special Essay: Russia, China and the New North Korean Leader." Operational Environment Watch 3(6), 53-56. Accessed at http://fmso.leavenworth.army.mil/OEWatch/ 201306/ 201306.html(October 14, 2015).

Kokoshin, Andrei A. 1998. Soviet Strategic Thought 1917-1991. London: The MIT Press.

Kraus, Charles. 2012. "Mutual Dependence in Sino-North Korean Relations: Evidence from the Chinese Civil War and the Korean War." SAIS Asia Conference, Washington D.C. (April 6).

Larson, D. W. and A. Shevchenko. 2003. "Shortcut to Greatness: The New Thinking and the Revolution in Soviet Foreign Policy." International Organization 57(1), 77-109.

Lincoln, W. Bruce.1989. Red Victory: A History of the Russian Civil War. New York, NY: Simon and Schuster.

Mastny, Vojtech. 1996. The Cold War and Soviet Insecurity: The Stalin Years. New York, NY: Oxford University Press.

Mawdsley, Evan. 2005. The Russian Civil War. Edinburgh, UK: Birlinn.

McDermott, Roger N. 2013. "Russia's Strategic Mobility: Supporting 'Hard Power' to 2020?” FOI (Swedish Defense Research Agency) Accessed at http://www.google.com/url?sa $=$ t\&rct $=\mathrm{j} \& \mathrm{q}=\&$ esrc $=$ s\&source $=$ web\&cd $=1$ \&ved=oCCMQFjAAahUKEwiMrtLg2tTHAhUk5qYKHS8tA9o\&url=http 
\%3A\%2F\%2Fwww.foi.se\%2FReportFiles\%2Ffoir_3587.pdf\&ei=rQLlVcy jAaTMmwWv2ozoDQ\&usg=AFQjCNF5pkn3kegn_Jf9sVVm4s_TlIF_w $\mathrm{Q}($ October 14, 2015).

Millet, Allan R.2005. The War for Korea, 1945-1950: A House Burning. Lawrence, KS: University of Kansas Press.

Omelicheva, Mariya Y. 2012. "Russian Foreign Policy." In Beasley, J. Kaarbo, J. Lantis, \& M. Snarr. eds. Foreign Policy in Comparative Perspective: Domestic and International Influences on State Behavior, 2nd Edition, Washington D.C.: CQ Press, 94-117.

. 2011. "Russian Security and Nuclear Policies: Successor to the Superpower Arsenal?” In R. A. Denemark. ed. International Studies Online, Accessed at http://www.isacompendium.com/public/online(October 14, 2015).

Osborn, Andrew. 2010. "Vladimir Putin's daughter to marry the son of South Korean admiral." Daily Telegraph (October 29). Accessed at http://www.telegraph.co.uk/news/worldnews/europe/russia/8097173/Vladimir-Putins-daughter-to-marry-the-son-of-SouthKorean-admiral.html(October 14, 2015).

Reese, Roger R. 1996. Stalin's Reluctant Soldiers, A Social History of the Red Army 1925-1941. Lawrence, KS: The University of Kansas Press.

Republic of Korea, Ministry of National Defense. 2010. The Joint CivilianMilitary Group Report. Accessed at http://news.bbc.co.uk/nol/shared/ bsp/hi/pdfs/20_05_10jigreport.pdf(October 14, 2015).

Rigmar, Erik. 2002. "The Recognition Game: Soviet Russian Against the West." Cooperation and Conflict 37 (2), 115-136.

Rittberger, Volker. 2004. "Approaches to the Study of Foreign Policy." International Relations Theories. Accessed at https://bibliographie.unituebingen.de/xmlui/bitstream/handle/10900/47326/pdf/tap46.pdf?se quence $=1$ \&isAllowed $=\mathrm{y}($ October 14, 2015).

Samuelson, Lennart. 2000. Plans for Stalin's War Machine: Tukhachevskii and Military-Economic Planning, 1925-1941. New York, NY: St. Martin Press. Schimmelpenninck van der Oye, David. 2001. Toward the Rising Sun: Russian Ideologies of Empire on the Path to War with Japan. Dekalb, IL: Northern Illinois University Press. . 2010. Russian Orientalism: Asia in the Russian Mind from Peter the Great to the Emigration. New Haven, CT: Yale University Press.

Sharpe, M.E. 2009. “The Tsarist Roots of Russia's Foreign Policy.” In Donaldson Robert H. and Joseph L. Nogee. eds. The Foreign Policy of Russia: Changing Systems, Enduring Interests, $4^{\text {th }}$ Edition. Armonk, NY: M.E. 
Sharpe, 16-33.

Shen, Zhihua and Danhui Li. 2011. After Leaning to One Side: China and Its Allies in the Cold War. Washington D.C.: Woodrow Wilson Center Press.

Shen, Zhihua. 2012. Mao, Stalin and the Korean War. London and New York, NY: Routledge.

Stoecker, Sally W. 1998. Forging Stalin's Army: Marshal Tukhachevsky and the Politics of Military Innovation. Boulder, CO: The Westview Press.

Stone, David R. 2000. Hammer and Rifle: The Militarization of the Soviet Union, 1926-1933. Lawrence, KS: University of Kansas Press. . 2006. A Military History of Russia: From Ivan the Terrible to the War in Chechnya. London: Praeger Security International.

Svechin, Aleksandr A. 1927. Strategy. Mostoc: Voennyivestnik.

Trotsky, Leon. 1923. How the Revolution Armed. Moscow: New Park Publications Ltd.

Tsygankov, Andrei P. 2010. Russia's Foreign Policy: Change and Continuity in National Identity. $2^{\text {nd }}$ Edition. New York, NY: Rowman\& Littlefield Publishers Inc.

Walt, S. 1998. "International Relations: One World Many Theories." Foreign Policy 110, 29-46.

Whiting, Allen S. 1960. China Cross the Yalu: The Decision To Enter the Korean War. Stanford, CA: Stanford University Press.

Wikipedia. 2015. "ROKS Cheonan sinking" (September 1). Accessed at http://en.wikipedia.org/wiki/ROKS_Cheonan_sinking(October 14, 2015). 